\title{
The Role of Mass Media as a Socialisation Agent in Shaping Behaviour of Primary School Pupils in Thika Sub-County, Kenya
}

\author{
Esther W. Mwangi ${ }^{1 *}$, Michael W. Gachahi ${ }^{1}$, Catherine W. Ndung'u ${ }^{1}$ \\ 1 School of Education and Social Sciences, Karatina University, KENYA
}

*Corresponding Author: esthermwangiw@gmail.com

Citation: Mwangi, E. W., Gachahi, M. W. and Ndung'u, C. W. (2019). The Role of Mass Media as a Socialisation Agent in Shaping Behaviour of Primary School Pupils in Thika Sub-County, Kenya. Pedagogical Research, 4(4), em0048. https://doi.org/10.29333/pr/5950

Published: October 2, 2019

\begin{abstract}
Children learn better when they socialise with items, tools and people in their environment. Provision of creative fun-filled environment boosts children's learning. Lack of a good socialising environment may affect a child's growth and development. The main goal of this study was to assess the role of mass media as a socialisation agent in shaping pupils' behaviour in primary schools in Thika Sub-County, Kenya. The study was guided by Albert Bandura's Imitative Observation Theory. This theory indicates that behaviour depicted by others is easily imitated by young children. The study adopted the descriptive survey research design. The target population comprised of 69 head teachers, 570 teachers, 3256 pupils and one Sub County Education officer. The study applied Gay Principle to determine the sample size of 7 head teachers, 57 teachers and 35 primary school pupils. Simple random sampling was applied to select the respondents who participated in the study. The main research instrument was the questionnaire. Data was analysed descriptively using Statistical Package for Social Sciences (SPSS) version 20. The study found that majority $(88.0 \%)$ of the teachers agreed that their pupils had access to mass media in form of television and Internet based media. The study noted only a very small proportion of children did not have access to mass media at home. The study concluded that at home, most children spend most of their time listening to radio, watching television programmes, or playing video games. The study recommends that parents must exercise control on the choice and exposure of their children to mass media.
\end{abstract}

Keywords: socialisation agents, mass media, behaviour development, child's behaviour

\section{INTRODUCTION}

Mass media has become a major social influencer. From the first years of childhood, the current generation of children are exposed to worrying volumes of audio-visual messages. The statistics point to an average of two hours, twenty minutes daily dedicated to mass mediaby the current young people and children (Anckle, 2011). Exposure to mass media is bound to impact on the children in either way (Anderson, 2014). Media is one of the main agents of socialisation that affect the youth most. Mass media covers the radio, television, and print. There is also electronic media such as computers, smart phones and IPads. Studies in developed countries have noted that mass media has great influence on children's behaviour (Baferani, 2015; Crisogen, 2015; Castro, 2017).

Esteve (2018) argued that mass media has become an important agent of socialisation of children, youth and adults. Mass media has a significant effect on children's development of communication and social skills among diverse populations worldwide. Rivière (2013) argued that advanced communication skills can be used for the explicit purpose of provoking learning which would facilitate socialisation and advancement of learners' attitudes. The role of mass media as an influencer of behaviour enables educators to develop educational broadcasts such as 
radio lessons, television lessons and educational web pages. However, socialisation promoted by mass media is indirect and takes a short time for adjusted behaviour to be manifested. Esteve (2018) further observed that the mass media assists in shaping behaviour through making propositions to people. These propositions assist in development of mental models that can be imposed with greater force and persuasion. The propositions are presented in a dramatic or emotional context that helps to inhibit the judgment critical. The study supported the findings in Pusateri and Liccardi (2015) that expressed most emphatically that the media, no longer report facts or, if they do, this is a secondary objective. The study noted that media was primary used for entertainment and thus most media houses have opted to reduce educative programmes. The current media has a primary role of entertaining the viewers; this makes the other roles such as education and information dissemination to be secondary goals. This is evident due to the organisation and volume of entertainment programmes offered by media houses. Analysis of the volume of time the media allocated to news and informative programmes have reduced significantly. Mass media belong to a group of opinion shapers with a significant role in shaping children's behaviour such as the family, the church or peers (Pusateri and Liccardi, 2015). Therefore, the media and its powerful network of influences are major socialisation agents and thus have a greater effect on children. This means that the media can complement, counter, enhance or nullify behaviour.

Mass media as a socialisation agent fulfils a very important socializing function. In the first place, the media provides information to people. This information is applied by people to construct the image to base their reality on. This reality created assist individuals to model and exhibit behaviour needed and thus form part of the information with which people construct the image of reality according to which people deploy their behaviours. Secondly, the media provide values, norms, models and symbols which people use in personal and social cohesion. Finally, it is through the media that personal identity is developed and built. Through interaction with the media an individual may develop their own definition applied in personal identity as an individual and a social person (Vera, 2010). Identity is a psychic need and social, since it contributes both to the maturity of the personality and to the social cohesion. The question is to know to what extent the means of communication is an entity capable of influencing a coherent direction or, on the contrary, of generating destruction.

\section{STATEMENT OF THE PROBLEM}

The current generation of children are exposed to various forms of media. The amount of time children spend on mass media compared to any other socialisation agents is a matter of concern to educationists. This exposure mostly is not under the control of adults since in most urban areas, children have access to internet connected smart phones, tablets, play station and other forms of video games. These mass media according to psychologists have an impact on the socio-psychological aspects of children. Recently in Kenya, there have been incidences of children taking part in demonstrations and mimicking the behaviour and songs sung by adults during demonstrations. Cases of learners stabbing and maiming one another as well as high level indiscipline and defiance of unprecedented scales have been cited in many educational institutions.

\section{PURPOSE OF THE STUDY}

The purpose of this study was to assess the role of mass media as a socialisation agent in shaping pupil's behaviour in primary schools in Thika Sub-County, Kenya.

\section{RESEARCH OBJECTIVE}

The study objective was to establish the role of mass media in shaping pupils' behaviour in primary schools in Thika Sub-County, Kenya.

\section{THEORETICAL FRAMEWORK}

This study was guided by Albert Bandura Theory of Imitative, Observational or Vicarious Learning.This theory holds that observational learning occurs when people copy positive of negative behaviour. Thus, a child's environment will determine the behaviour manifested. Cloninger (2013) apparently makes it clear that, behaviour is highly acquired and maintained in the presence of a model and when the model is absent, the behaviour is still maintained. This is demonstrated when children watch a video of drawings or series of superheroes and imitate what they have seen. Bravo (2016) suggests that there are two forms of learning; observational or vicarious. Observational learning is when people modify their behaviours by observing others that are rewarded or punished 
and feel as if they had experienced the consequences themselves. Vicarious learning is the second type where one imitates a conduct where there is no reward or punishment for demonstrating a behaviour pattern. Thus, simply because the model exhibits something that one wants to learn, such behaviour is thus imitated. The way of learning that children in this case apply is that of observational learning not rewarded or punished, because nobody intervenes in the motivation to imitate the superheroes, they will freely repeat behaviour that is often depicted by their favourite mass media characters. Chapi (2012) noted that Bandura observed that behaviour modelling is given through different influences: the family, the child's peers as well as mass media. Chapi argued that parents and others who surround children are models to imitate, and may arise, also that parents get configured in their children. Further, Chapi (2012) noted that a child was observed to copy the behaviour of other children in the same environment. The children also imitated behaviour depicted by the images and visuals on mass media which includes video games, television, and child's magazines among others.

\section{LITERATURE REVIEW}

A study by Browne and Hamilton-Giachritsis (2015), noted that exposure to violence stimulated the same in children leading to other phenomena, including desensitization of children. The audience produces a habituation to violence, with the installation of a passivity and apathy in the face of violent acts. Some children and adolescents are more vulnerable and susceptible than others (Browne and Hamilton-Giachritsis, 2015). Van-Felitzen and Carlson (2009) suggested that every person may be negatively influenced by media violence but the effects are different depending on the equipment, subject and according to the child's physical and social environment. Gender analysis on the effect of mass media indicated that men were more desensitized than women after exposure to violence. Temperament is also a factor of vulnerability, and it was noted that men with high aggression were more vulnerable compared with less aggressive men.

The American Academy of Paediatrics (2011) denounced exposure to violence in the media, including television, film, games video and music as a significant risk factor for the health of children and adolescents. Violence experienced through the media contributes to aggressive behaviour, desensitization acts of violence, nightmares and fear of being assaulted. The attention of paediatricians was drawn to the fact that the practice of violent games increased from $13 \%$ to $22 \%$ of violent behaviour among children. In these games, the player is the aggressor and he is rewarded if his behaviour succeeds. This phenomenon of reward then leads to the repetitive exhibition of the behaviour leading to normalisation of behaviour. The study by American Academy of Paediatrics (2011) showed that majority of programmes transmitted by the media passively or interactively were violent, and this stimulated violence and aggression among media consumers. The study showed that children and adolescents were very vulnerable, and the media targeted them in their programmes. Therefore, the adolescents were continuously exposed to unlimited images of violence and this increased aggression rates among adolescents.

Huimin (2015) observed that childhood is the basic socialisation stage of individual development which plays a foundation for the entire socialisation process. During childhood, an individual gradually forms an independent world outlook; on life, values, constructs a personal behavioural norm and evaluation system. The individual also adapts to the self and surrounding role clusters and initially cultivates his own sociality. Among the many factors affecting the socialisation of individuals, mass media has become an important external force that affects the development of people, especially children. The media tools and the media communication content constitute the dual factors that media influence children's socialisation.

In Spain, Garitaonandia, Juaristi, Oleaga and Pastor (2008), carried out a qualitative and quantitative study on the effect of mass media on children. This study was carried out among Spanish speaking households in European countries which included the Great Britain, Spain, France, Germany, Italy, Spain, Holland, Sweden, Finland, Denmark, Switzerland and Israel. In the study, the main aim was to conceptualise the effect of mass media on Spanish children in these countries. The study compared the uses, effects, attitudes and behaviour of children aged six years to sixteen years, parents of urban families who have children of those ages; and the teachers of educational centres with the corresponding training cycles. It shows that children watch television almost every day of the week (an average of 5.8 days per week). The study further showed that girls dedicate around two hours and fifteen minutes per day, while the boys had an additional 3 minutes exposure. With regard to age, it was observed that older people have high levels of daily exposure compared to young people. Specifically, the difference was 15 minutes which was marginal in this case. Thus young children were exposed to mass media almost at the same rate as adults. Perez, Rodríguez, Navas and Polyecsko (2008), also observed that children have long exposure to mass media and mostly occurs without an adult supervision. The findings were interesting in that the data showed that $100 \%$ of the children claimed to watch TV every day. The study also found out that $57 \%$ of the children had access to television for a period ranging between two to three hours daily. Perez, Rodríguez, Navas and Polyecsko (2008), established that a significant proportion of children $(34 \%)$ had access to uncontrolled media for up to five hours daily. Data also showed that $69 \%$ of children dictated the television programme to watch without adult supervision. 
Kadiri and Mohammed (2011) noted that television and other broadcast media have had a tremendous effect on young people since the discovery of television sets. The conversation of the impact of the television sets and shaping people's behaviour arose after liberalisation of the airwaves. The new players did not have stringent government control and the broadcasters had the independence to select what programmes to air to the masses. However, there have been serious concerns about the impact of mass media on pupils' behaviour since the discovery of the television set. Cable and satellite television played a key role in defining the popular culture in the 1960s and 1970s. The rate of information dissemination from one corner of the world to another was greatly enhanced. Through media explosion across continents, people across the oceans started to imitate the characters on television and behaviour patterns were altered to fit in the television characters. One of the key components of mass media were the movies from Hollywood and Hong Kong film makers. Celebrities such as Kardashians, Tiger woods, Beckham and many others form the conversations of children and young people (Giddens, 2006). Okafor and Malizu (2013) noted that the media may be directly utilized for education and creating positive impact on children behaviour or it can be used as a tool for indoctrination of children. This would revolve around exposing children to mass media devoid of violence and foul language. This would inculcate positive values that yield socially acceptable behaviour. Indoctrination would result in moulding negative and anti-social behaviour to children.

Gbadeyan (2009) indicated that since early 1950s, in Nigeria there had been growing pressure by teachers, social scientists and parents to state governors and other elected representatives to advocate for reduction of the level of violence exposed to children through television programmes and on the video games. Kadiri and Mohammed (2011) noted that other than violent and foul language in mass media, many parents worry that the quality of the messages and the volume of advertising directed at children has increased. Mass media has elevated children and the youth into a pedestal where they claim them to be guiding and determining their destiny. Mass media has subjugated the role of parents to passive members of the society and elevated the children and young people as the key behavioural decision makers and thus children and young people are more likely to dictate behaviour to adults. However, in most instances, this behaviour is one depicted by mass media as the norm in movies and video games. Adults have been assumed to be minority and this has led to skyrocketing cases of juvenile delinquency (Kadiri and Mohammed, 2011).

Prot, Anderson, Gentile, Warburton, Saleem, Groves and Brown, (2015) carried out an evaluation of mass media's influence on the lifestyle of youths in Delta State, Nigeria. The study argued that the current generation of young people's behaviour has been shaped by mass media more than the earlier generations where the community had a communal responsibility to shape young people's behaviour. The study noted that mass media explosion that started in the 1950s with television has drastically increased to include digital, print and traditional media. The expansion of fibre cables has also seen an extensive coverage and access to the internet as well as smart phones. Internet access through smart phones has compounded issues since almost all regions in the world can now access the internet. The development of entertainment software and web-based entertainment sites improved people's access to mass media across the continents. This has enhanced cultural exchanges among the people across continents. The study argued that parents must constantly enlighten themselves on the various mass media their children are exposed to if they desire to keep up with mass media revolution. Thus, the authors argue that a child growing up today is faced with diverse media that is fighting to shape their behaviour. Mass media particularly the television and the internet has increased the volume of information that children access. However, the study noted that unchecked access to mass media may lead to information overload and this would alter the child's socialisation skills. Through imitation, the child is likely to adopt certain behaviour patterns depicted by mass media characters. Mass media has greatly influenced the way children relate to one another. The study noted that children who spent considerable time on mass media are aggressive in nature. Prot, Anderson, Gentile, Warburton, Saleem, Groves and Brown (2015) further noted that when children are constantly exposed to violent media, increased their level of aggression. The study noted that most children programmes are centred on physical or verbal violence. The study by Prot et al. (2015) argued that children cartoon series are always presented with a character who was fighting some villain. Thus children get to perceive the world as a dangerous place for them and they must fight back to conquer the world. Thus, children were prone to be violent and aggressive (Prot et al., 2015).

\section{METHODOLOGY}

\section{Research Design}

Descriptive survey design was adopted in this study. This design was appropriate since the study sought to establish how mass media has influenced pupils' behaviour. The study was carried out in a region with 43 public primary schools, 26 private primary schools in Thika Sub-County in Kenya. The region is located $45 \mathrm{~km}$ North East of Nairobi, Kenya's Capital City. The region had one sub county director of education, 69 head teachers, 570 teachers and 3,256 class seven pupils. Simple random sampling was used to select 57 teachers' as study respondents. 
Pedagogical Research, 4(4), em0048

Table 1. Mass Media and Pupils' behaviour

\begin{tabular}{|c|c|c|c|c|c|}
\hline Statement & $\begin{array}{l}\text { Strongly } \\
\text { Agree }\end{array}$ & Agree & $\begin{array}{c}\text { Non- } \\
\text { Committal } \\
\end{array}$ & Disagree & $\begin{array}{l}\text { Strongly } \\
\text { Disagree }\end{array}$ \\
\hline $\begin{array}{l}\text { At home children are exposed to mass Media (Radio, TV, } \\
\text { Video Games, you tube and other web based media....) }\end{array}$ & $\begin{array}{c}25 \\
46.30 \% \\
\end{array}$ & $\begin{array}{c}22 \\
40.70 \% \\
\end{array}$ & $\begin{array}{c}0 \\
0.00 \% \\
\end{array}$ & $\begin{array}{c}7 \\
13.00 \% \\
\end{array}$ & $\begin{array}{c}0 \\
0.00 \% \\
\end{array}$ \\
\hline $\begin{array}{l}\text { Children spend considerable time on Radio/TV /Video } \\
\text { Games }\end{array}$ & $\begin{array}{c}11 \\
20.4 \%\end{array}$ & $\begin{array}{c}28 \\
53.70 \%\end{array}$ & $\begin{array}{c}0 \\
0.00 \%\end{array}$ & $\begin{array}{c}7 \\
13 \%\end{array}$ & $\begin{array}{c}7 \\
13.00 \%\end{array}$ \\
\hline $\begin{array}{l}\text { Children dance to the latest music videos and the dances } \\
\text { correspond to dance moves in the media }\end{array}$ & $\begin{array}{c}13 \\
25.9 \% \\
\end{array}$ & $\begin{array}{c}21 \\
38.90 \% \\
\end{array}$ & $\begin{array}{c}4 \\
7.40 \% \\
\end{array}$ & $\begin{array}{c}11 \\
20.40 \% \\
\end{array}$ & $\begin{array}{c}4 \\
7.40 \% \\
\end{array}$ \\
\hline Children's language depicts what they see on TV & $\begin{array}{c}15 \\
29.6 \%\end{array}$ & $\begin{array}{c}25 \\
46.30 \%\end{array}$ & $\begin{array}{c}0 \\
0.00 \%\end{array}$ & $\begin{array}{c}8 \\
14.80 \%\end{array}$ & $\begin{array}{c}5 \\
9.30 \%\end{array}$ \\
\hline Children's interaction is similar to what they see on TV & $\begin{array}{c}11 \\
22.2 \%\end{array}$ & $\begin{array}{c}28 \\
51.90 \%\end{array}$ & $\begin{array}{c}5 \\
9.30 \%\end{array}$ & $\begin{array}{c}3 \\
5.60 \%\end{array}$ & $\begin{array}{c}6 \\
11.10 \%\end{array}$ \\
\hline
\end{tabular}

The teacher's questionnaire was the main instrument for data. Collaborative data was provided by the interview guide held with the sub county director of education. A head teacher's interview guide was also used to collect secondary data to collaborate the teacher's questionnaire. Data was collected, organised into themes and coded. The data was then entered into the computer for analysis using descriptive statistics with aid of Statistical Package for Social Sciences.

\section{FINDINGS AND DISCUSSION}

The study sought to assess the role of mass media as a socialisation agent in shaping pupils' behaviour in primary schools in Thika Sub-County, Kenya. Data in Table 1 shows that majority $(88.0 \%)$ of the teachers agreed that their pupils had access to mass media in form of television and internet based media. The study noted only a very small proportion (13\%) of children did not have access to mass media at home. The study sought to establish the average amount of time that children spent on mass media. Data showed that majority $(74.1 \%)$ of the teachers agreed that a large amount of free time at home is spent on mass media (watching television and playing video games among other mass media activities). The head teachers noted that with introduction of tablets in education, some of the children operated the tablets effortlessly compared to some adults. A good number of children were observed to carry out Google search with great ease. Data showed that majority of the head teachers and pupils shared the opinion that mass media had a tremendous effect on learner's behaviour and language. The study established that majority of children in Thika Sub-County, Kenya are exposed to mass media at home. The study found out that at home, most children spend most of their time either on listening to radio, watching television programmes, watching music on mass media, or playing video games. This finding concurs with Giddens (2006) who noted that children had more access and exposure to mass media than any other previous generation. Giddens further argued that the exposure level ranges from application of hand held devices, computers, radio, television and video games. Giddens (2006) noted that this exposure could either be positive or negative depending on the content that the children are exposed to through all these media. The study concluded that children at tender age have access to a wide range of print, electronic and digital mass media such as television, video games, you-tube and other webbased media. However, mass media can be positively used to develop the children's talent while at the same time, if unmanaged could be destructive and corrupt children's behaviour.

The study sought to establish the choice of songs and dancing styles exhibited by children coincided with dancing styles in the televisions and other mass media. Data showed that majority (64.8\%) of the teachers noted that the children dancing moves were a replica of the dance moves on most popular music programmes on television and the latest moves on the latest hit songs in Kenya. The participants were also asked if the language used by learners coincided with language used in mass media. Data showed that majority $(75.9 \%)$ of the teachers noted that most learners' language was commensurate to mass media language. The findings were collaborated with the head teachers who were interviewed. In fact, as one head teacher noted, when one child was reprimanded for foul language, the defence was that their cartoon character used the words frequently without being punished. This shows that the children copy the language of their role model which includes the cartoon characters. The study determined that young children copy the language of their role models formed by mass media particularly the television. Some of the dance moves were dirty dance styles reserved for adult entertainment. Thus, mass media shaped the children's behaviour and continuous unmanned exposure was detrimental to children. The study concurs with Okafor and Malizu (2013) who posited that mass media particularly the television have both positive and negative effects on children. Although mass media has negative effects, at the same time there are some particular educative and very informative programmes on television that assist learners to develop social skills, critical thinking skills and problem solving skills. These skills are key to socio-development of children and assist 
to model children's behaviour. Finally, all the participants indicated that mass media has had a great influence in the general behaviour of children in the region.

\section{CONCLUSIONS}

The study concluded that children in the urban and peri-urban areas of Kenya are exposed to a wide variety of mass media. Majority of the children in Kenya had access to television, video games and music videos; that children had access to a wide variety of mass media ranging from traditional to modern media; that children in the region exhibited behaviour that was corresponding to the types of mass media they were exposed to; that children's language and dance movements were a replica of the content in mass media; that children gained vulgar language and words from the interaction with mass media. The researcher also concluded that mass media has great impact on the children's behaviour and as such the choice of media exposure was important.

\section{RECOMMENDATIONS}

The study made several recommendations based on the findings discussed. That every Kenyan parent must exercise control on the choice of mass media their children are exposed to; that parents must also control the volume of mass media content accessed by their children this could be by limiting the time spent on mass media such as video games time, time spent of television among other mass media. The parents need to vouch the content of mass media that their children are exposed to ensure that they avoid negative effects of mass media; that schools should sensitise the parents on the critical role played by mass media on children's behaviour. This would enlighten the parents and assist them to make best decisions regarding their children's exposure to mass media. During the parents meetings, parents should be taught by behavioural experts on how mass media may corrupt good morals and at the same time develop better personalities on children depending on the content that the children are exposed to. The study suggested that a study on the role of teachers in children play activity and socio-cognitive development of young children be conducted.

The researcher recommends that the government needs to exercise control on mass-media content that the young children are exposed to. The study discovered that in Kenya, soap opera with adult content was aired at times when the children and parents were awake and this influenced the language and behaviour of children significantly. The study recommends that such programmes be restricted to late night hours. Finally, the Ministry of Education, Science and Technology should incorporate sensitisation programmes for parents to underscore the role of mass media has on their child's behaviour. The study recommends a study on the impact of children playing violent computer games on emotional intelligence of children be carried out.

\section{REFERENCES}

American Academy of Paediatrics. (2011). Media violence. Committee on Public Education. Pediatrics, 108(1), 12221226. Available at: https://www.ncbi.nlm.nih.gov/pubmed/11694708 (Accessed 7 March 2016)

Anderson, C. A. (2014). An update on the effects of playing violent videogames. Journal of Adolescents, 27(1), 113122. https://doi.org/10.1016/j.adolescence.2003.10.009

Baferani, M. H (2015). The role of family in the socialisation of children. Mediterranean Journal of Social Science, 6(6), 417-434. https://doi.org/10.5901/mjss.2015.v6n6s6p417

Browne, K. D. and Hamilton-Giachritsis, C. (2005). The influence of violent media on children and adolescents: A public-health approach. Lancet, 365(1), 702-710. https://doi.org/10.1016/S0140-6736(05)70938-7

Castro, A. (2017). Challenges of the new educational scenario: Children, parents and educators walking together towards the 21st century. Eastern Journal of Education, 3(2), 107-109.

Chapi, J. L. (2012). A psychological revision to the theories of aggressiveness Electronic Journal of Psychology Iztacala, $4(1), 88-90$.

Crisogen, D. T. (2015). Factors that may cause failure in school socialisation. A cumulative approach. International Journal of Management and Applied Science, 1(11), 140-143.

Devashish, M. and Trindade, V. (2005). Inequality and Trade. Canadian Joumal of Economics, 38(4), 43-47. https://doi.org/10.1111/j.0008-4085.2005.00324.x

Esteve, J. M. (2018). The third educational revolution. Education in the knowledge society. Barcelona: Paidó.

Garitaonandia, C., Juaristi, P. and Oleaga, J. A. (2008). What do Spanish children see and how they play? The use that children and young people make the media. Available at: www.quadernsdigitals.net/articles/zer/zer6/z6queven.html (Accessed 14 March 2016) 
Gbadeyan, R. A. (2009). Children's perception of television commercial in Lagos State, Nigeria. International MultiDisciplinary Journal, 3(2), 334-346. https:/ / doi.org/10.4314/afrrev.v3i2.43634

Giddens, A. (2006). Sociology (5th Ed). New York: Polity Press.

Huimin, M. (2015). Research on the Influence of electronic media on children's socialization. Beinjin Journal of Social Sciences, 3(2), 12-19. Available at: http://cdmd.cnki.com.cn/Article/CDMD-10459-1014385272.htm (Accessed 14 March 2018)

Kadiri, K. and Mohammed, A. (2011). Mass media as correlates of children's behavioural problems in Kwara State, Nigeria. Journal of Media and Communication Studies, 3(5), 198-202.

Muszyńska, M. (2010). Education and education and gender. Studia Edukacyjne, 5(1), 93-109.

Mwaura, J. K. (2015). Relationship between levels of exposure to mass media and students' deviant behaviours in selected secondary schools, Nakuru County, Kenya (Unpublished MeD Thesis), Kenyatta University, Nairobi.

Ocharo, M. C. and Karani, S.E. (2015).Effects of mass media on the academic development of children in primary schools in Kenya: A case study of St. Alloys Junior Academy. International Journal of Novel Research in Education and Learning, 2(2), 11-18.

Okafor, G. O. and Malizu, C. F. (2013).The Nigerian mass media and childhood socialization. Journal of Humanities and Social Science, 16(5), 06-10. https://doi.org/10.9790/0837-1650610

Pérez, L. C., Rodríguez L., Navas V. S. and Polyecsko C. M. (2008). What co children watch on TV ? Determination of television habits in children from 6 to 8 years old. Available at: http:/ / cyberpediatria.com/porquetv.htm (Accessed 26 November 2017)

Prot, S., Anderson, C. A., Gentile, D. A., Warburton, W., Saleem, M., Groves, C. L. and Brown, S. C. (2015). Media as agents of socialisation. In J.E. Grusec and P. D. Hastings (Eds.), Handbook of Socialization (second edition) (pp. 276-300). New York, NY: Guilford Press.

Pusateri, M. D. and Liccardi, I. (2015). The pedagogical role of children's media (Unpublished Thesis), University of Palermo, Palermo.

UNESCO. (2001). Focusing Resources on effective school health: A FRESH start to enhancing the quality and equity of education. World Education Forum 2000, Final Report. Dakar, Senegal.

Van-Felitzen, C. and Carlson, U. (2009) Children and media: image, education, participation; Children and media violence. UNESCO, Gothenburg. 